G.A. Potasheva

MGSU

\title{
INVESTMENT ASPECT IN MATERIAL INCENTIVE OF HUMAN RESOURCES
}

\section{ИНВЕСТИЦИОННЫЙ АСПЕКТ \\ В МАТЕРИАЛЬНОМ \\ СТИМУЛИРОВАНИИ ЧЕЛОВЕЧЕСКИХ РЕСУРСОВ}

Аннотация. Рассматривается ценность интеллектуальных ресурсов в современной экономике, благодаря которой активы человеческих ресурсов стали одним из факторов формирования стоимости систем на основе их инвестирования. Адекватная оценка деятельности работников как одного из основных ресурсов позволит выдержать конкуренцию в условиях «выживания» посредством периодического формирования социальноэкономического профиля и стимулирования инвестиций в человеческие ресурсы на основе следующих технологий: формирования сбалансированной системы показателей, создания механизма образования и распределения фондов оплаты труда, использования принципа золотого сечения.

Ключевые слова: сбалансированная система показателей, механизм образования и распределения фондов оплаты труда, принцип золотого сечения

DOI: $10.22227 / 2305-5502.2017 .1 .4$
Abstract. Value of intellectual resources in modern economy due to which the assets of human resources became one of the factors of formation of value of systems on the basis of their investing, is considered. Adequate evaluation of employees' activities as one of the basic resources will make it possible to meet competition under conditions of "survival" through periodic formation of socio-economic profile and stimulation of investment in human resources on the basis of the following technologies: formation of a balanced scorecard system, creation of a mechanism of formation and distribution of labour compensation funds, use of the golden section principle. Establishment of wages according to the golden section principle contributes to the stability and commitment of employees and increase of efficiency of investments in human resources, provided that it doubles the sales volume and should accordingly increase the wages of each employee by a factor of 1.62. Statistical analysis demonstrated that organizations that work using the golden section principle increased the labour productivity on average by $10-20$ $\%$, augmented the turnover by a factor of 1.3-1.5, minimized the costs by 15-20\%. Application of the golden section technology creates conditions necessary for economic growth on the basis of efficiency of investments in human resources.

Key words: balanced scorecard system, mechanism of formation and distribution of wage funds, the golden section principle

DOI: $10.22227 / 2305-5502.2017 .1 .4$
Понимание ценности интеллектуальных ресурсов в современной экономике привело к тому, что активы человеческих ресурсов стали одним из факторов формирования стоимости систем. По мнению Я. Фиценца, в оценке человеческих ресурсов должен отражаться фактор воздействия деятельности работников на достижение целей организации, что позволяет структурировать эффективность работы, сформировав модель оценки человеческих ресурсов на трех уровнях: организации; структурного подразделения; управления [1].

Измерение прибыльности человеческих ресурсов в рамках данной модели возможно производить на основе системы сбалансированных показателей, подразделив их на финансовые и «человеческие».

К финансовым можно отнести следующие показатели:

- прибыль как отношение прибыли организации к эквиваленту полной занятости (ЭПЗ);
Understanding of the value of intellectual resources in modern economy resulted in the fact that the assets of human resources became one of the factors of systems cost formation. In the opinion of Ya. Fitsents, in the evaluation of human resources the factor of employees' activities impact on achievement of the organization goals must reflect, and that will make it possible to structure the work efficiency, forming a model of evaluation of human resources at three levels: organization; structural unit; management [1].

Measurement of profitability of human resources in terms of this model can be performed on the basis of the balanced scorecard system, having divided the metrics into financial and "human".

Financial metrics include the following :

- profit as a profit of organization - full time equivalent (EPZ) ratio; 
- расходы на заработную плату;

- инвестиционные показатели, отражающие эффективность вложений в работников (ROI (return on investment) - окупаемость инвестиций, HCI $_{\min }$ (human capital investment) — минимальный уровень инвестиций);

- добавленная стоимость, определяемая

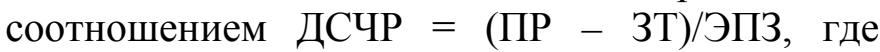
ДСЧР - добавленная стоимость человеческих ресурсов, ПР - прибыль, 3Т - затраты на функционирование человеческих ресурсов (без учета заработной платы);

- рыночная стоимость человеческих ресурсов - отношение разности между рыночной и балансовой стоимостью к ЭПЗ.

Оценку эффективности инвестиций возможно рассматривать в следующих аспектах: для работников (социальный эффект) и для организации (коммерческий):

- оценка социальной эффективности расчет показателя $\mathrm{HCI}_{\min }$ и его сопоставление со средней заработной платой;

- оценка экономической эффективности расчет ROI инвестиционного проекта и его анализ) [1].

При оценке социальной эффективности капиталовложений основным показателем является минимальный уровень капиталовложений в человека $\mathrm{HCI}_{\min }$ - денежное выражение инвестиичии, которые необходимь для нормального функционирования проекта, учитывающий затраты человека, обеспечивающие ему нормальное существование:

$$
\mathrm{HCI}_{\min }=\sum_{i=1}^{n} Z_{i},
$$

где $Z_{i}=Z_{i}\left(C_{i j}, N_{i j}\right)$ - сумма затрат в месяц на функционирование человеческих ресурсов, зависящая от цен на услуги $C_{i j}$ и норм потребления $N_{i j}$.

Результат расчета $\mathrm{HCI}_{\min }$ (являющийся количественным выражением социального эффекта) необходимо сопоставить с заработной платой работников. Если заработная плата работника меньше, чем $\mathrm{HCI}_{\min }$, инвестиции используются неэффективно и не позволяют удовлетворять необходимые потребности. Если же заработная плата находится на одном уровне с $\mathrm{HCI}_{\min }$, инвестиции используются эффективно.

Оценка экономического эффекта осуществляется после реализации инвестиционного проекта, связанного с работниками, на основе показателя ROI - «окупаемость инвестиций»:
- wage disbursement;

- investment metrics reflecting the efficiency of investment in employees (ROI - return on investment, $\mathrm{HCI}_{\min }$ minimum level of human capital investments);

- added value defined by relationship $\mathrm{DSChR}=(\mathrm{PR}-\mathrm{ZT}) / \mathrm{EPZ}$, where DSChR human resources added value, PR - profit, $\mathrm{ZT}$ - human resources functioning costs (excluding wages and salaries);

- market value of human resources, or the market and book value difference EPZ ratio.

Evaluation of efficiency of investments can be considered in the following aspects: for employees (social effect) and for organization (business effect):

- evaluation of social efficiency calculation of the $\mathrm{HCI}_{\min }$ metric and its comparison with average wages;

- evaluation of economic efficiency calculation of ROI of investment project and its analysis) [1].

In assessing of the social efficiency of investments the basic metric is the minimum level of investments in a human, $\mathrm{HCI}_{\min }-$ monetary value of the investments that are necessary for the normal functioning of the project, taking into account the costs of a human ensuring a normal life for him:

$$
\mathrm{HCI}_{\min }=\sum_{i=1}^{n} Z_{i},
$$

where $Z_{i}=Z_{i}\left(C_{i j}, N_{i j}\right)$ - amount of costs per month for functioning of human resources depending on service prices $C_{i j}$ and consumption rates $N_{i j}$.

The result of calculation of $\mathrm{HCI}_{\text {min }}$ (which is a quantification of the social effect) should be compared with the wages of employees. If an employee's wage is less than $\mathrm{HCI}_{\min }$, the investments are used inefficiently and do not allow to satisfy the needs. If a wage is at the same level with $\mathrm{HCI}_{\min }$, the investments are used efficiently.

Evaluation of economic effect is performed after implementation of the investment project associated with employees, based on the ROI — "return on investment" metric: 


$$
\mathrm{ROI}=\frac{\Delta D-Z}{Z} 100 \%
$$

где $\Delta D-$ прирост доходов после реализации проекта; $Z$ - прямые и косвенные затраты на реализацию проекта.

Если значение ROI $<20 \%$, то инвестиции неэффективны (20 \% - стандартный норматив для организации). Если 20 \% < ROI < 150 \%, проект эффективен. Организации, «агрессивно» развивающие бизнес, должны ориентироваться на ROI около 150-200 \%, что требует дополнительного анализа.

Адекватная оценка человеческих ресурсов как основных позволит выдержать конкуренцию в условиях «выживания» посредством периодического формирования социальноэкономического профиля [1].

Для повышения эффективности использования инвестиций в человеческие ресурсы на микроэкономическом уровне возможно использовать сбалансированную систему показателей, механизм образования и распределения фондов оплаты труда и приниип золотого сечения.

Технология сбалансированной системы показателей, разработанная Р. Капланом, Д. Нортоном, рассматривает базовую структуру мотивации - систему согласования целей и систему стоимостной мотивации (рис. 1).

$$
\mathrm{ROI}=\frac{\Delta D-Z}{Z} 100 \%,
$$

where $\Delta D$ - earnings gain after implementation of the project; $Z$ - direct and indirect costs of the project implementation.

If the ROI $<20 \%$ the investments are inefficient (20\% - the standard normative for organization). If $20 \%<\mathrm{ROI}<150 \%$, the project is efficient. Organizations that develop business "aggressively" must focus on the ROI of about 150-200 \% which requires further analysis.

Adequate evaluation of human resources as the basic ones will make it possible to meet competition under conditions of "survival" by means of periodic formation of socio-economic profile [1].

To improve the efficiency of use of investments in human resources at microeconomic level it is possible to use the balanced scorecard system, the mechanism of formation and distribution of wage funds, and the golden section principle.

The balanced scorecard technology developed by R. Kaplan and D. Norton, considers the underlying structure of motivation - the goals harmonization system and the cost motivation system (Fig. 1).

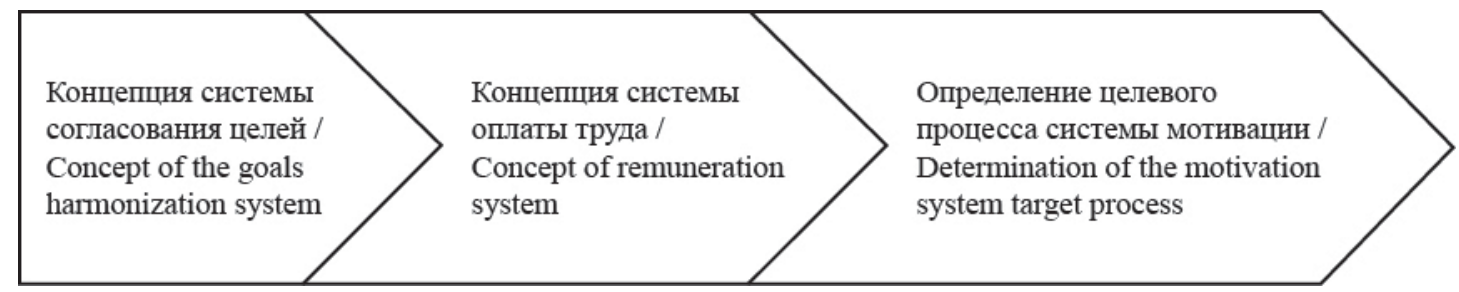

Рис. 1. Алгоритм разработки системы мотивации rithm

Fig. 1. Motivation system development algo-

Система согласования целей предполагает для формулирования целей определить уровни иерархии организации, функциональных подразделений, отделов и работников (рис. 2). В рамках сбалансированной системы показателей цели структурных подразделений и характеризующих их показателей выводятся из карты целей организации. Для индивидуального уровня целей осуществляется согласование целей с работником, которые измеряют его вклад в достижение целей [2].
The goals harmonization system suggests, for formulating of goals, to define the hierarchy levels of organization, functional units, departments and employees (Fig. 2). In terms of the balanced scorecard, the goals of structural units and metrics characterizing them are derived from the organization's goals chart. For individual level of goals, harmonizations of goals with employee which measure his contribution to achievement of the goals, are performed [2]. 


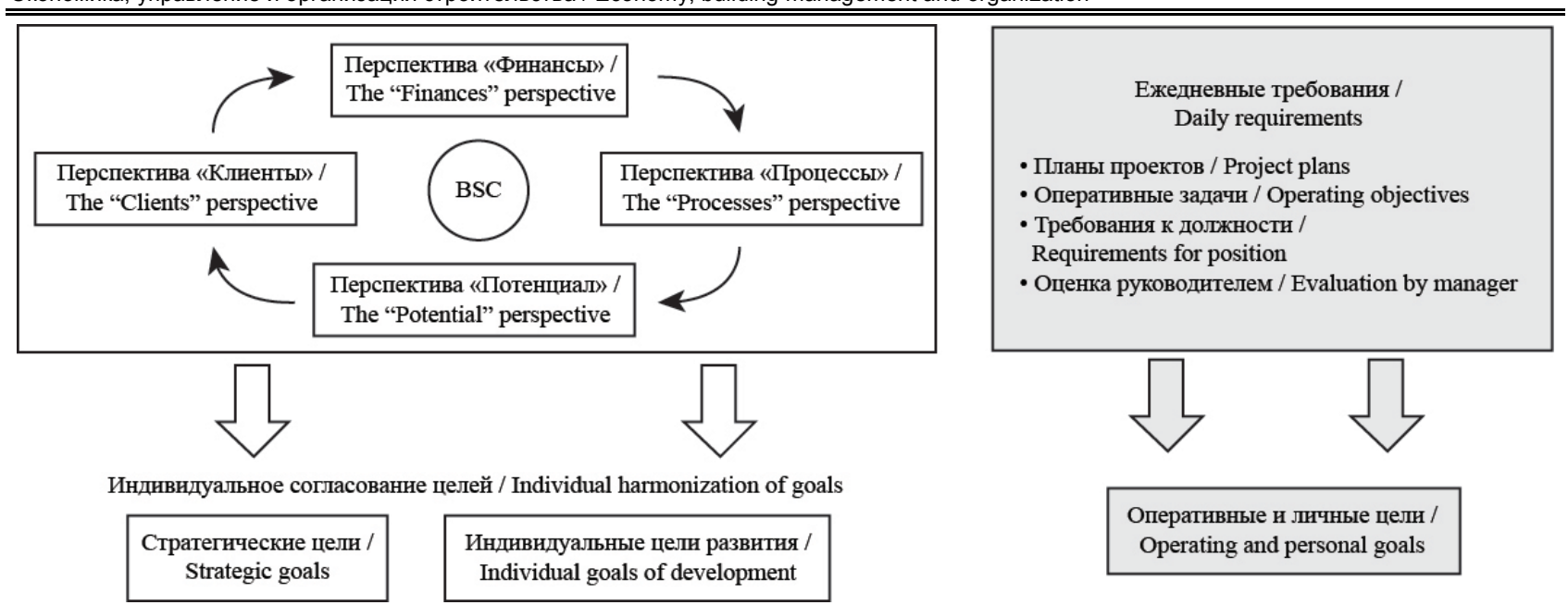

Рис. 2. Сбалансированная система показателей как источник формирования индивидуальных целей

Fig. 2. Balanced scorecard system as the source of formation of individual goals

Для измерения степени достижения целей

For measuring of the goals achieveиспользуются номинальный, ординальный или кардинальный метод (рис. 3) [2].

extent, the nominal, ordinal or cardinal method is used (Fig. 3) [2].

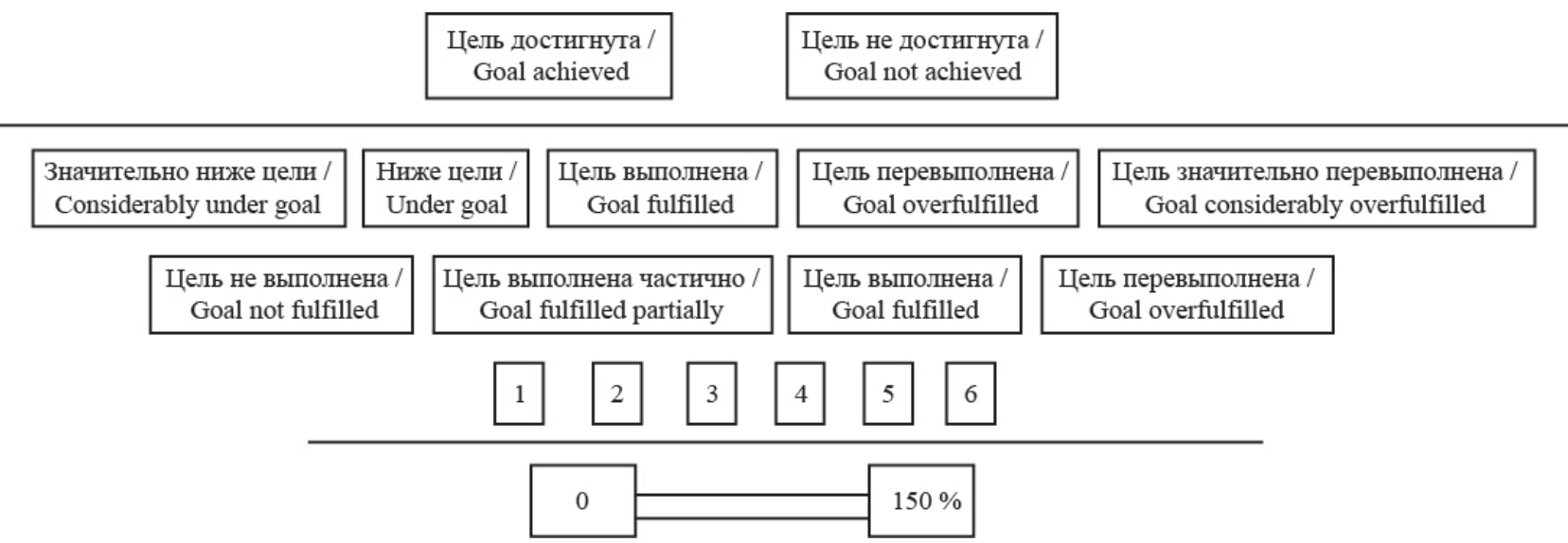

Рис. 3. Методы оценки степени достижения цели

Кониепџия системы оплаты труда в рамках системы мотивации предполагает, что материальная мотивация может быть дополнена нематериальной, сбалансированной по форме и структуре. Так, в структуре системы мотивации (в ее переменной части) следует учитывать два параметра: стимулирующее воздействие и согласие. При увеличении доли переменной части системы оплаты труда возрастет ее стимулирующее воздействие, но начинает снижаться акцептабельность (приемлемость).

Процесс согласования целей и оплаты труда в рамках системы мотивации включает формирование стратегии, разработку целей и целевых показателей в сбалансированной системе (путем каскадирования целей) (табл. 1).
Fig. 3. Techniques of goal achievement extent evaluation

The concept of remuneration system within the motivation system implies that material motivation can be supplemented by nonmaterial motivation, balanced in form and structure. Thus, in the motivation system structure (in its variable part) two parameters should be taken into account: stimulating effect and consent. At increasing of the remuneration system variable part share its stimulating effect increases, but acceptability starts to decrease.

Procedure of harmonization of goals and remuneration within the system of motivation includes the formation of strategy, development of goals and targets in the balanced system (by cascading of goals) (table. 1). 
Табл. 1. Формуляр для процесса согласования целей
Table 1. Data card for the goals harmonization process

\begin{tabular}{|c|c|c|c|c|c|c|c|c|}
\hline \multicolumn{5}{|c|}{$\begin{array}{r}\text { Фамилия работника / } \\
\text { Surname of employee }\end{array}$} & \multicolumn{4}{|c|}{$\begin{array}{l}\text { Учетный номер / } \\
\text { Account number }\end{array}$} \\
\hline \multirow{2}{*}{$\begin{array}{l}\text { № / } \\
\text { №. }\end{array}$} & \multirow{2}{*}{$\begin{array}{c}\text { Цель } \\
/ \\
\text { Goal }\end{array}$} & \multirow{2}{*}{$\begin{array}{c}\text { Bec / } \\
\text { Weight }\end{array}$} & \multicolumn{4}{|c|}{ Оценка / Evaluation } & \multirow[b]{2}{*}{$\begin{array}{c}\text { Вес × сте- } \\
\text { пень дости- } \\
\text { жения цели / } \\
\text { Weight } \times \\
\text { Goal } \\
\text { achievement } \\
\text { extent }\end{array}$} & \multirow{2}{*}{$\begin{array}{c}\text { Коммен- } \\
\text { тарии / } \\
\text { Com- } \\
\text { ments }\end{array}$} \\
\hline & & & $\begin{array}{c}\text { Цель не } \\
\text { достигнута } \\
\text { / Goal not } \\
\text { achieved } \\
0\end{array}$ & $\begin{array}{c}\text { Цель } \\
\text { достигнута } \\
\text { / Goal } \\
\text { achieved } \\
0,5 . .0,9\end{array}$ & $\begin{array}{c}\text { Цель } \\
\text { достигнута } \\
\text { / Goal } \\
\text { achieved } \\
1\end{array}$ & $\begin{array}{c}\text { Цель перевы- } \\
\text { полнена / Goal } \\
\text { overfulfilled } \\
1,1 \ldots 1,5\end{array}$ & & \\
\hline
\end{tabular}

Стратегические цели и мероприятия (из перспектив «Финансы», «Клиенты», «Процессы») / Strategic goals and measures (from the "Finances”, "Clients”, "Processes” perspectives)

\begin{tabular}{l|l|l|l|l|l|l|l|l}
\hline & & & & & & & & \\
\\
\hline
\end{tabular}

Индивидуальные цели развития и мероприятия (из перспективы «Потенциал») / Individual goals of development and measures (from the "Potential” perspective)

\begin{tabular}{l|l|l|l|l|l|l|l|l}
\hline & & & & & & & \\
\hline & & & & & & & & \\
\hline \\
\hline
\end{tabular}

Оперативные и прочие личные цели / Operating and other personal goals

\begin{tabular}{l|l|l|l|l|l|l|l|l}
\hline & & & & & & & \\
\hline & & & & & & & & \\
\\
\hline
\end{tabular}

Сумма / Amount

Индивидуальная степень достижения целей / Individual goals achievement extent

Проводится оценка достижения целей и определяется необходимость их корректирования. Результатом оценки является определение величины переменной части в заработной плате, и, если цели достигнуты, выплачивается переменная часть системы мотивации (рис. 4) [2].
Evaluation of the goals achievement is performed, and necessity of their correction is determined. Result of the evaluation is determination of the variable part value in remuneration, and, if the goals are achieved, the variable part of the motivation system is paid (Fig. 4) [2].

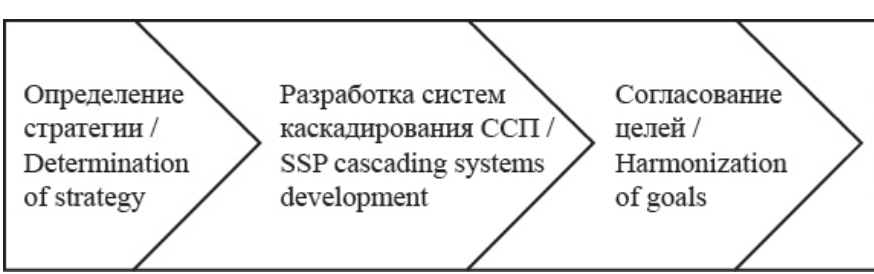

Рис. 4. Согласование целей и оплата труда: ССП - сбалансированная система показателей

Для повышения эффективности инвестиций возможно гармоничное распределение доходов в рамках сбалансированной системы показателей. Так, В.Г. Кандалинцев предложил процедуру снижения и декомпозиции целей/показателей до уровня отдельных работников, которая позволяет разработать стратегические карты, стратегический бизнес-план, бюджет и в финансовом аспекте перевести

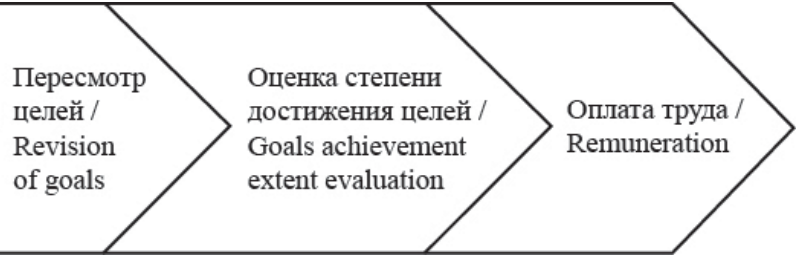

Fig. 4. Harmonization of goals and remuneration: SSP — the balanced scorecard system

In order to improve the efficiency of investments, it is possible to perform a harmonious distribution of income within the balanced scorecard system. So, V.G. Kandalintsev proposed a procedure of reduction and decomposition of the goals/metrics to the level of individual employees; the procedure enables you to develop strategic charts, strategic business plan, budget, and to transfer, 
стратегию на операционный уровень. В данном случае используется декомпозиция показателей результативности и их закрепление за подразделениями (так как управлять мы может только тем, что в состоянии измерить). Полученный набор ключевых показателей результативности $\mathrm{KPI}_{s}$ (Key Performance Indicators) используется в стратегическом плане для формирования плановой динамики ключевых показателей результативности стратегического горизонта. Coвокупность таких стратегических задач определит совокупность бонусных направлений in financial aspect, the strategy to the operational level. In this case, decomposition of performance indicators and allocation of them to subdivisions are used (as we can manage only something that we are able to measure). The resulting set of key performance indicators $\left(\mathrm{KPI}_{s}\right)$ is used in the strategic plan for formation of planned dynamics of the key performance indicators of strategic horizon. The aggregate of such strategic objectives will define the aggregate of bonus directions (Fig. 5) [3]. (рис. 5) [3].

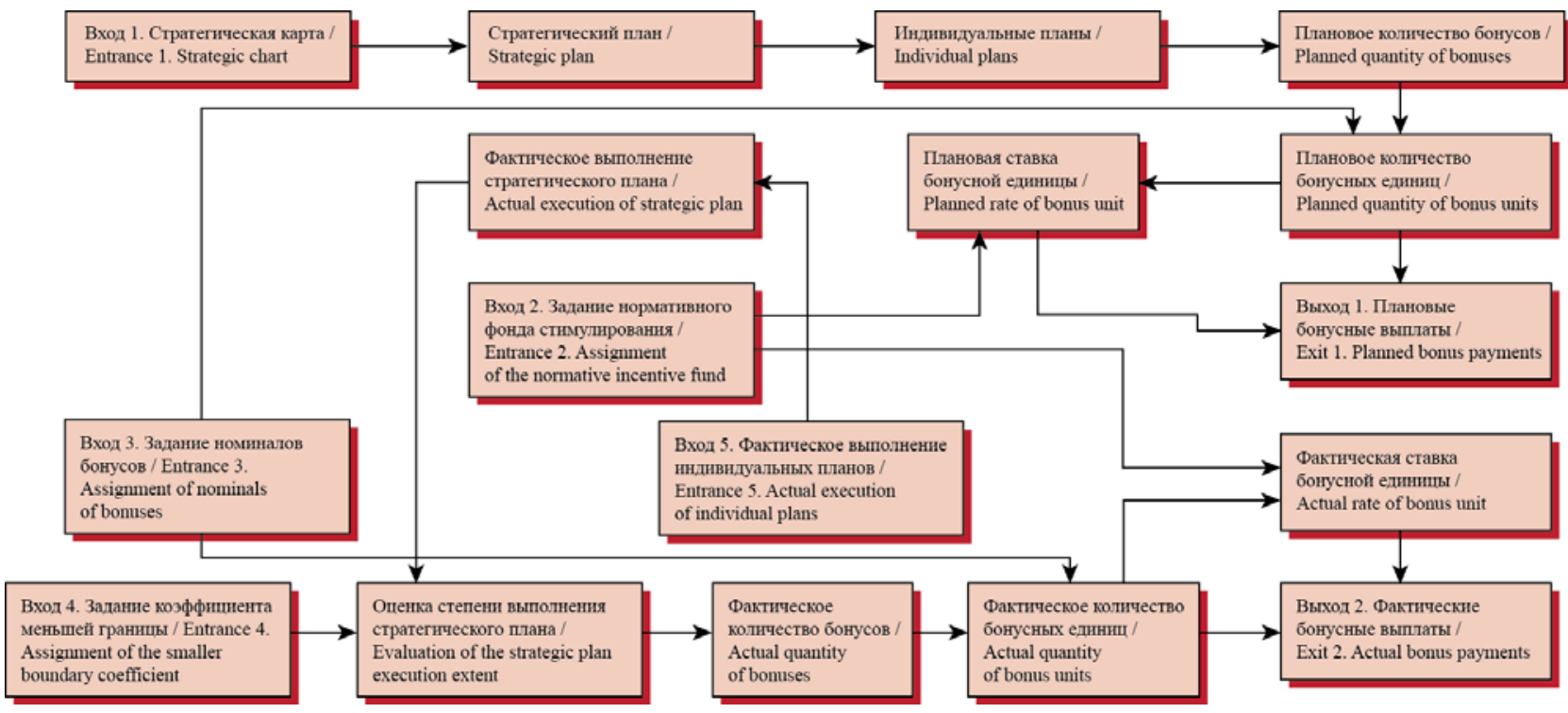

Рис. 5. Последовательность обработки информации в сбалансированном вознаграждении

В каждом бонусном направлении определяются получатели бонусов, которых, согласно исследованиям В.Г. Кандалинцева, определяют по следующими параметрам [3]:

- количество бонусов - число (1), которое подлежит распределению;

- номинал бонуса - число, выражающее значимость бонуса (номинал бонуса - 30, бонус за соблюдение сроков - 20);

- количество бонусных единиц $(1 \times 30=30)$;

- ставка бонусной единицы - сумма, которую выплачивают за бонусную единицу (5000 руб.);

- бонусные выплаты - результат перемножения ставки бонусной на количество бонусных единиц $(5000 \times 30=150000$ руб. $)$.

Индивидуальные достижения учитываются через начисление $y$ бонусных единиц, а коллективный результат — через установление ставки бонусной единицы. Смысл двоякого
Fig. 5. Information processing sequence in the balanced remuneration

In each bonus direction the recipients of bonuses are defined; according to the research of V.G. Kandalintsev, they are defined by the following parameters [3]:

- quantity of bonuses - the number (1) which is subject to distribution;

- nominal of bonus - the number which expresses significance of the bonus (nominal of bonus - 30, bonus for compliance with deadlines - 20);

- quantity of bonus units $(1 \times 30=30)$;

- rate of bonus unit - the amount paid for a bonus unit (5 000 roubles);

- bonus payments - the result of multiplying the bonus rate by quantity of bonus units $(5000 \times 30=150000$ roubles $)$.

Individual achievements are recorded through the accrual $y$ of bonus units, and the collective result - through establishment of the rate of bonus unit. The meaning of a dual 
подхода заключается в том, что бонусная система поощряет как индивидуальную результативность, так и заинтересованность работников в достижении целей организации.

Процессы системы сбалансированного вознаграждения состоят из планирования бонусных выплат и их расчета по факту, который производится на основе трех подходов:

- стратегическая карта - стратегический план - индивидуальные планы - плановое количество бонусов;

- задание нормативного фонда стимулирования;

- задание номиналов бонусов.

Так, цель - рост объема заключенных договоров измеряется показателем «объем заключенных за период договоров, руб.», которая декомпозирована с помощью коэффициентов распределения: Иванов - 0,4; Петров - 0,3; Сидоров - 0,3 (номинал бонуса -10 , количество бонусов - 1, плановая ставка - 5000 руб.). Тогда Иванову причитается бонусная выплата в размере $10 \times 1 \times 0,4 \times 5000$ руб. $=$ $=20000$ руб.

Плановая ставка бонусной единицы определяется делением фонда материального стимулирования на количество всех бонусных единиц. Фонд материального стимулирования корректируется в зависимости от фактических результатов работы стимулирования [3].

По каждому ключевому показателю определяется степень выполнения плана. Для этого необходимо вычислить степень выполнения стратегической задачи в баллах (по 10балльной шкале) на основе коэффициента меньшей границы. При равенстве результата значению коэффициента меньшей границы присваивается значение 0 баллов. Если результат оказывается больше, ему выставляют до 10 баллов, что означает достижение планового рубежа [3]. Затем «взвешиваются» ключевые показатели, и с помощью балльной оценки выполнения стратегических задач вычисляется средневзвешенная оценка выполнения всей совокупности стратегических задач. На следующем этапе рассчитывается величина фактического фонда материального стимулирования: величина нормативного фонда умножается на коэффициент, соответствующий степени выполнения стратегического плана. Величину фактического фонда материального стимулирования делят на количество бонусных единиц и рассчитывают ставку бонусной единицы. approach is that the bonus system encourages both individual effectiveness and commitment of employees to achievement of the organization goals.

Processes of the balanced remuneration system consist of the planning of bonus payments and calculation thereof on actual basis that is performed based on three approaches:

- strategic chart — strategic plan - individual plans - planned quantity of bonuses;

- assignment of the normative incentive fund;

- assignment of nominals of bonuses.

Thus, the goal - growth of volume of concluded contracts is measured by the "volume of concluded contracts during the period, roubles" metric, and this goal is decomposed using the distribution coefficients: Ivanov - 0.4; Petrov - 0.3; Sidorov - 0.3 (nominal of bonus - 10, quantity of bonuses -1 , planned rate -5000 roubles). Then, Ivanov is owed a bonus payment in the amount of $10 \times 1 \times 0.4 \times 5000$ roubles $=$ $=20000$ roubles.

Planned rate of bonus unit is determined by dividing the material incentive fund by the quantity of all bonus units. The material incentive fund is adjusted depending on the actual results of the incentive functioning [3].

For each key indicator the plan execution extent is determined. For this, it is necessary to calculate the strategic objective execution extent in scores (on a 10-score scale) on the basis of the smaller boundary coefficient. In case of equality of result, the value of the smaller boundary coefficient is assigned a value of 0 scores. If the result is higher, it is assigned up to 10 scores, which means the achievement of the planned milestone [3]. Then the key indicators are "weighed", and, by using the score evaluation of execution of strategic objectives, the average weighed evaluation of execution of the entire set of strategic objectives is calculated. At the next stage the value of actual material incentive fund is calculated: the value of normative fund is multiplied by a factor corresponding to the strategic plan execution extent. The actual material incentive fund value is divided by the quantity of bonus units, and the rate of a bonus unit is calculated. 
Фактическое количество бонусных единиц подсчитывается по следующему алгоритму:

- определяется количество фактических бонусных единиц на каждом бонусном направлении (обычно 1);

- это значение умножается на коэффициент, соответствующий степени выполнения плана по ключевому показателю результативности (10-балльной шкале);

- фактическое количество бонусов направления умножается на номинал бонуса, что характеризует фактическое количество бонусных единиц;

- рассчитываются все бонусные единицы, в результате получаем общее количество бонусных единиц, используемое при расчете фактической ставки бонусной единицы;

- определяются размеры индивидуальных выплат.

Так, на направлении «Объем заключенных договоров» при коэффициенте меньшей границы 0,8, плане 10 млн руб., фактическом объеме 9 млн руб. получена оценка выполнения плана 5 баллов, фактическое количество бонусов $-1 \times 5$ баллов $/ 10=0,5$, а фактические коэффициенты распределения составили: Иванов — 0,55 (5 млн руб./9 млн руб.), Петров - 0,33 (3 млн руб./9 млн руб.), Сидоров - 0,12 (1 млн руб./9 млн руб.). Тогда размер бонусной выплаты Иванову составит 10 (номинал бонуса) $\times 0,5$ (фактическое количество бонусов) $\times 0,55$ (личный фактический коэффициент распределения) $\times 6000$ руб. (фактическая ставка бонусной единицы) = 16500 руб. Предлагаемая В.Г. Кандалинцевым система позволяет сформировать целый спектр многообразных стимулов работы [3].

Рассмотрим концепичю механизма образования и распределения фондов оплаты труда. Моделью бестарифной системы оплаты труда, разработанной специалистами Российской академии государственной службы (РАГС) при Президенте Российской Федерации, является использование «вилки» соотношений оплаты труда разного качества (ВСОТэРКа), суть которой состоит в том, что все работники в зависимости от их квалификации, должности, профессии, функций подразделяются на группы.

Суть ВСОТэРКа заключается в том, что минимальные значения этого показателя $\mathrm{K}_{i}$ соответствуют исходной квалификационной
The actual quantity of bonus units is calculated as per the following algorithm:

- quantity of actual bonus units in each bonus direction (typically 1) is determined;

- this value is multiplied by the coefficient corresponding to the plan execution extent as per the key performance indicator (on a 10-score scale);

- actual quantity of bonuses of direction is multiplied by the nominal of bonus; this characterizes the actual quantity of bonus units;

- all bonus units are calculated; as a result, we get the total quantity of bonus units used in calculation of the actual rate of bonus unit;

- sizes of individual payments are determined.

Thus, in the "Volume of concluded contracts" direction, with the smaller boundary coefficient $=0.8$, plan $=10 \mathrm{mln}$. roubles, the actual volume $=9 \mathrm{mln}$. roubles, the following data were received: plan execution evaluation $=5$ scores, the actual quantity of bonuses $=1 \times 5$ scores $/ 10=0.5$, and the actual distribution coefficients amounted to: Ivanov $=0.55(5 \mathrm{mln}$. roubles $/ 9 \mathrm{mln}$. roubles $)$, Petrov $=0.33$ (3 mln. roubles $/ 9 \mathrm{mln}$. roubles $)$, Sidorov $=0.12(1 \mathrm{mln}$. roubles $/ 9$ mln. roubles). Then the size of the bonus payment to Ivanov will amount to 10 (nominal of bonus) $\times 0.5$ (actual amount of bonuses) $\times 0.55$ (personal actual distribution coefficient) $\times 6000$ roubles (actual rate of bonus unit) $=16500$ roubles. The system proposed by V.G. Kandalintsev makes it possible to form an entire range of diverse incentives for work [3].

Let's consider the concept of mechanism of formation and distribution of wage funds. Model of tariff-free wage system developed by experts of the Russian Academy of State Service (RAGS) at the President of the Russian Federation, is the use of a "fork" of correlations of remuneration of various quality (VSOTeRKa), the essence of which is that all employees depending on their qualifications, positions, professions, functions, are divided into groups.

The essence of VSOTeRKa is that the minimal values of this metric $K_{i}$ comply with the initial qualification group (the lowest 
группе (самой низкой квалификации), внутреннее соотношение может быть, например, $1,0 \ldots 1,8$ при среднем значении диапазона 1,4 и амплитуде «вилки» + 0,4. Рассчитав для каждого работника конкретное значение ВСОТэРКа по сравнению с минимальным $K_{i}$, можно определить размер заработной платы работника $3 \Pi_{i}$ по формуле

$$
3 \Pi_{i}=\frac{K_{i} T_{i}}{\sum_{i=1}^{n} K_{i} T_{i}} \text { ФОТ, }
$$

где $3 \Pi_{i}-$ размер заработной платы $i$-го работника; $n$ - общая численность работников; $K_{i}-$ коэффициент, показывающий соотношение с минимальным значением; $T_{i}$ - количество рабочего времени, отработанного работником.

Особенностью данной концепции является наличие в структуре заработной платы трех ставок: трудовой, особой (учитывающей специфические условия труда) и личной. Базовой величиной является трудовая ставка, основанная на разряде и категории работника. Систему трудовых ставок можно представить в виде матричной формы, где 10 столбцов соответсвуют общему количеству категорий, 18 строк - разрядам (табл. 2)

Табл. 2. Система трудовых ставок в виде матричной формы qualification), and internal correlation can be, for example, $1.0 \ldots 1.8$, with an average value of range 1.4 and amplitude of "fork" +0.4 . Having calculated for each employee a specific VSOTeRKa value in comparison with the minimal $\mathrm{Ki}$, it is possible to determine the wage rate of employee $\mathrm{ZP}_{i}$ as per formula

$$
3 \Pi_{i}=\frac{K_{i} T_{i}}{\sum_{i=1}^{n} K_{i} T_{i}} \text { ФОТ, }
$$

where $\mathrm{ZP}_{i}$ - wage rate of employee $i$; $n$ total number of employees; $K_{i}$ - coefficient showing the correlation with the minimal value; $\mathrm{T}_{i}$ - quantity of labour time worked by employee.

The peculiarity of this concept is the presence of three rates in the wage structure : labour, special (considering specific labour conditions) and personal. Base value is the labour rate based on the class and the category of employee. The system of labour rates can be represented as a matrix form where 10 columns correspond to the total number of categories, 18 lines - to the classes (table. 2)

Table 2. System of labour rates as a matrix

\begin{tabular}{|c|c|c|c|c|c|c|c|c|c|c|}
\hline \multirow{2}{*}{$\begin{array}{c}\text { Разряды / } \\
\text { Classes }\end{array}$} & \multicolumn{10}{|c|}{ Категория работников / Category of employees } \\
\hline & 1 & 2 & 3 & 4 & 5 & 6 & 7 & 8 & 9 & 10 \\
\hline 1 & 1330 & 1530 & 1836 & 2258 & 2845 & 3556 & 4516 & 5780 & 7398 & 9469 \\
\hline 2 & 1343 & 1544 & 1853 & 2279 & 2871 & 3589 & 4558 & 5834 & 7467 & 9558 \\
\hline 3 & 1357 & 1561 & 1873 & 2304 & 2903 & 3629 & 4608 & 5852 & 7491 & 9588 \\
\hline 4 & 1370 & 1575 & 1890 & 2325 & 2929 & 3661 & 4649 & 5951 & 7617 & 9750 \\
\hline 5 & 1384 & 1592 & 1910 & 2349 & 2960 & 3700 & 4698 & 6014 & 7698 & 9853 \\
\hline 6 & 1398 & 1608 & 1929 & 2373 & 2990 & 3737 & 4746 & 6075 & 7776 & 9953 \\
\hline 7 & 1412 & 1624 & 1949 & 2397 & 3020 & 3775 & 4794 & 6088 & 7792 & 9974 \\
\hline 8 & 1426 & 1640 & 1968 & 2421 & 3050 & 3812 & 4841 & 6196 & 7931 & 10152 \\
\hline 9 & 1440 & 1656 & 1987 & 2444 & 3079 & 3849 & 4889 & 6258 & 8010 & 10253 \\
\hline 10 & 1454 & 1672 & 2006 & 2468 & 3109 & 3886 & 4935 & 6317 & 8086 & 10350 \\
\hline 11 & 1468 & 1688 & 2026 & 2492 & 3139 & 3924 & 4983 & 6378 & 8164 & 10450 \\
\hline 12 & 1483 & 1705 & 2046 & 2517 & 3171 & 3964 & 5034 & 6443 & 8247 & 10556 \\
\hline 13 & 1498 & 1723 & 2067 & 2542 & 3203 & 4004 & 5085 & 6509 & 8331 & 10664 \\
\hline 14 & 1513 & 1740 & 2087 & 2567 & 3234 & 4043 & 5134 & 6572 & 9412 & 12047 \\
\hline 15 & 1528 & 1757 & 2108 & 2593 & 3267 & 4084 & 5187 & 6639 & 8498 & 10877 \\
\hline 16 & 1543 & 1774 & 2129 & 2619 & 3300 & 4125 & 5239 & 6706 & 8584 & 10987 \\
\hline 17 & 1558 & 1792 & 2150 & 2644 & 3331 & 4164 & 5288 & 6769 & 8664 & 11090 \\
\hline 18 & 1573 & 1809 & 2171 & 2670 & 3364 & 4205 & 5340 & 6835 & 8749 & 11199 \\
\hline
\end{tabular}
form 
Рабочим-повременщикам присваеваются категории с 1-й по 6-ю; служащим - с 3-й по 5-ю; специалистам - с 4-й по 7-ю; руководителям - с 5-й по 10-ю.

Трудовая ставка - это корректируемая величина, в структуру которой входит тарифный заработок, должностной оклад, премии, доплаты. При невыполнении работы трудовая ставка уменьшается на $15 \%$; при переводе на другую оплату труда — на $27 \%$; при отказе от выполнения задания - на 75 \%. Трудовая ставка снижается на 10 \% для лиц, уволившихся по собственному желанию; на 30 \% - уволенным за нарушение трудовой дисциплины; на 25 \% совершившим прогул; на 1-26 \% - за нарушение правил безопасности.

У административно-управленческого персонала трудовая ставка может снижаться за невыполнение обязанностей - до $20 \%$, за недобросовестное составление отчетности до $10 \%$, за нарушение трудового распорядка до $10 \%$.

Диапазон «вилки» работников соответствующей категории будет определятся межразрядным соотношением коэффициентов.

При расчете конкретного значения $K_{i}\left(K_{\text {инт }}\right)$ внутри «вилки» необходимо воспользоваться графической зависимостью между $\mathrm{K}_{\text {инт }}$ и $\mathrm{У}_{\text {кв }}$ (уровнем квалификации в баллах). При этом диапазон значений $K_{\text {инт }}$ (ось ординат) определяется диапазоном сквозной «вилки»: для рабочихповременщиков он составляет $1,00 \ldots 4,46$; для служащих - 1,38...3,56; для специалистов $1,71 \ldots 5,97$; для руководителей - 2,16...13,14.

Табл. 3. «Вилка» интегральных коэффициентов трудовой ставки работников
Timeworkers are given categories from 1 to 6; office workers - from 3 to 5; experts - from 4 to 7; managers from 5 to 10.

Labour rate is a correctable value, the structure of which includes tariff earnings, position salary, bonuses, additional payments. At failure to do the work the labour rate is reduced by $15 \%$, at transfer to another wage - by $27 \%$; at refusal of task performance - by $75 \%$. Labour rate is reduced by $10 \%$ for persons who left for personal reason; by $30 \%$ - for the dismissed for violation of labour discipline; by $25 \%$ - for those who committed truancy; by 1-26\% - for violation of safety rules.

For the administrative staff the labour rate may be reduced for neglect of duty up to $20 \%$, for unconscientious reporting up to $10 \%$, for violation of labour regulations - up to $10 \%$.

The range of "fork" for employees of the appropriate category will be determined by inter-class correlation of coefficients.

At calculation of the specific value $K_{i}$ $\left(K_{\text {итн }}\right)$ inside the "fork" it is necessary to use a characteristic curve between $K_{\text {инт }}$ и $\mathrm{V}_{\text {кв }}$ (qualification level in scores). Hereat, the range of values $\mathrm{K}_{\text {инт }}$ (Y-axis) is determined by the range of a through "fork": for timeworkers it is $1.00 \ldots 4.46$; for office workers - $1.38 \ldots$ 3.56, for experts 1.71...5.97; for managers - 2.16...13.14.

Table 3. A "fork" of integral coefficients of a labour rate of employees

\begin{tabular}{c|c|c|r}
\hline \multirow{2}{*}{$\begin{array}{c}\text { Категория работника / } \\
\text { Category of employee }\end{array}$} & \multicolumn{2}{|c}{ Характеристики «вилки» / Characteristics of the “fork” } \\
\cline { 2 - 4 } & Диапазон / Range & $\begin{array}{c}\text { Среднеe значение / Average } \\
\text { value }\end{array}$ & Aмплитуда / Amplitude \\
\hline 1 & $1,00 \ldots 1,62$ & 1,31 & $\pm 0,31$ \\
\hline 2 & $1,15 \ldots 1,85$ & 1,50 & $\pm 0,35$ \\
\hline 3 & $1,38 \ldots 2,22$ & 1,80 & $\pm 0,42$ \\
\hline 4 & $1,71 \ldots 2,85$ & 2,28 & $\pm 0,57$ \\
\hline 5 & $2,16 \ldots 3,56$ & 2,86 & $\pm 0,70$ \\
\hline 6 & $2,70 \ldots 4,46$ & 3,58 & $\pm 1,26$ \\
\hline 7 & $3,45 \ldots 5,97$ & 4,71 & $\pm 1,79$ \\
\hline 9 & $4,42 \ldots 8,00$ & 6,21 & $\pm 2,30$ \\
\hline
\end{tabular}


Табл. 4. Сетка соотношений в оплате труда работников
Table 4. Scale of correlations in remuneration of employees

\begin{tabular}{|c|c|c|c|c|c|c|c|c|c|c|}
\hline \multirow{2}{*}{$\begin{array}{l}\text { Основные категории работников / } \\
\text { Basic categories of employees }\end{array}$} & \multicolumn{10}{|c|}{$\begin{array}{l}\text { «Вилка» соотношений в оплате труда по квалификационным группам работников / } \\
\text { “Fork” of correlations in remuneration as per qualification groups of employees }\end{array}$} \\
\hline & 1 & 2 & 3 & 4 & 5 & 6 & 7 & 8 & 9 & 10 \\
\hline $\begin{array}{l}\text { Неквалифицированные Рабочие } \\
\text { (1-3 категории) / Non-qualified } \\
\text { workers (1-3 categories) }\end{array}$ & $\begin{array}{c}1,00 \ldots \\
1,62\end{array}$ & $\begin{array}{c}1,15 \ldots \\
1,85\end{array}$ & $\begin{array}{c}1,38 \ldots \\
2,22\end{array}$ & & & & & & & \\
\hline $\begin{array}{l}\text { Квалифицированные рабочие } \\
\text { (4-6 категории) / Qualified workers } \\
\text { (4-6 categories) }\end{array}$ & & & & $\begin{array}{c}1,71 \ldots \\
2,85\end{array}$ & $\begin{array}{c}2,16 \ldots \\
3,56\end{array}$ & $\begin{array}{c}2,70 \ldots \\
4,46\end{array}$ & & & & \\
\hline $\begin{array}{l}\text { Служащие (3-5 категории) / } \\
\text { Office workers (3-5 categories) }\end{array}$ & & & $\begin{array}{c}1,38 \ldots \\
2,22\end{array}$ & $\begin{array}{c}1,71 \ldots \\
2,85\end{array}$ & $\begin{array}{c}2,16 \ldots \\
3,56\end{array}$ & & & & & \\
\hline $\begin{array}{l}\text { Специалисты (4-7 категории) / } \\
\text { Experts (4-7 categories) }\end{array}$ & & & & $\begin{array}{c}1,71 \ldots \\
2,85\end{array}$ & $\begin{array}{c}2,16 \ldots \\
3,56\end{array}$ & $\begin{array}{c}2,70 \ldots \\
4,46\end{array}$ & $\begin{array}{c}3,45 \ldots \\
5,97\end{array}$ & & & \\
\hline $\begin{array}{l}\text { Руководители (7-9 категории) / } \\
\text { Managers (7-9 categories) }\end{array}$ & & & & & $\begin{array}{c}2,16 \ldots \\
3,56\end{array}$ & $\begin{array}{c}2,70 \ldots \\
4,46\end{array}$ & & & & \\
\hline $\begin{array}{l}\text { Руководители среднего уровня } \\
\text { (7-9 категории) / Mid-level execu- } \\
\text { tives (7-9 categories) }\end{array}$ & & & & & & & $\begin{array}{c}3,45 \ldots \\
5,97\end{array}$ & $\begin{array}{c}4,42 \ldots \\
8,00\end{array}$ & $\begin{array}{l}5,66 \ldots \\
10,26\end{array}$ & \\
\hline $\begin{array}{l}\text { Руководители высшего уровня } \\
\text { (директор, гл. инженер и их заме- } \\
\text { стители) (10 категория) / C-level } \\
\text { executives (director, chief engineer } \\
\text { and their deputies) (10 category) }\end{array}$ & & & & & & & & & & $\begin{array}{l}7,26 \ldots \\
13,14\end{array}$ \\
\hline
\end{tabular}

Методика оценки уровня конкурентоспо-

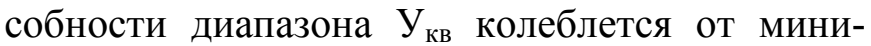
мально допустимого до максимально возможного (10 баллов). В условиях неопределенности понятия «квалификация работника» его значение меняется. Так, при оценке квалификации рабочих используется система, учитывающая тарифный разряд рабочего по ЕТКСТ; освоение рабочим дополнительных профессий (1,5 балла); освоение смежных профессий (1 балл); творческий потенциал (0,2 балла). Следовательно, определение конкретного $K_{\text {инт }}\left(K_{i}\right)$ с помощью выведения графической зависимости эффективно и более просто, но процесс подготовки достаточно трудоемкий.

Концеепџия принциипа золотого сечения, рассмотренная И.В. Прангишвили [4], позволяет повысить эффективность инвестиций в человеческие ресурсы на основе гармоничного распределения доходов по принципу золотого сечения с помощью ряда Фибоначчи, в котором каждый последующий член равен сумме двух предыдущих:

$$
a_{n}=a_{n-1},+a_{n-2} .
$$

Так, если необходимо распределить фонд заработной платы между пятью работниками по принципу золотого сечения, первому работнику
The $\mathrm{y}_{\text {кв }}$ range competitiveness level evaluation technique varies from the minimum permissible to the maximum possible (10 scores). In conditions of vagueness of the "qualification of employee" notion its value changes. Thus, when evaluating the qualification of workers, the system that takes into account a worker's tariff class as per ETKST; mastering of additional professions by a worker (1.5 scores); mastering of allied professions (1 score); creative potential (0.2 scores). Therefore, determination of specific $\mathrm{K}_{\text {инт }}\left(\mathrm{K}_{i}\right)$ by means of deriving of characteristic curve is efficient and more simple but the preparation process is quite labourconsuming.

The golden section principle concept considered by I.V. Prangishvili [4] permits to increase the efficiency of investments in human resources on the basis of harmonious distribution of income according to the Golden section principle using the Fibonacci series in which each subsequent term is equal to the sum of the previous two:

$$
a_{n}=a_{n-1},+a_{n-2} \text {. }
$$

Thus, if it is necessary to distribute the wage fund among five employees according 
выделяется минимальная заработная плата, например 1000 руб., следующему по должности следует начислить на 62 \% больше, т.е. 1620 руб. Третьему по должности уже необходимо установить заработную плату $a_{n}=a_{n-1}+a_{n-2}=$ $1000+1620=2620$ руб., а четвертому $-a_{n}=a_{n-}$ $1+a_{n-2}=1620+2620=4240$ руб., пятому, самому вышестоящему по должности, необходимо установить заработную плату $a_{n}+a_{n-1}+a_{n-2}$ $=2620+4240=6860$ руб. [4].

Так как сложная система, как правило, содержит два блока: производственнотехнологический и социально-экономический, то в основе эффективного управления системой должно лежать гармоничное сочетание этих блоков. Поэтому И.В. Прангишвили предлагает для устойчивости и гармонии в кадровой политике заработную плату работникам формировать по принципу золотого сечения: заработная плата работника более высокого уровня иерархии должна быть на $62 \%$ больше заработной платы работника предыдущего уровня (табл. 5).

Табл. 5. Расчет численности иерархии штатных сотрудников и их заработной платы to the principle of golden section, the first employee is allocated a minimal wage, for example, 1000 roubles, the following as per position should be paid 62\% more, i.e. 1620 roubles. It is necessary to establish a salary for the third as per position $a_{n}=a_{n-1}+a_{n-2}=$ $1000+1620=2620$ roubles, for the fourth $a_{n}=a_{n-1}+a_{n-2}=1620+2620=4240$ roubles; for the fifth, the most superior as per position, it is necessary to establish a salary $a_{n}+a_{n-1}+a_{n-2}=2620+4240=6860$ roubles. [4].

As a complex system typically contains two blocks: industrial-technological and socio-economical, a harmonious combination of these blocks must be in the basis of the effective management of the system. Therefore, I.V. Prangishvili proposes,for stability and harmony in personnel policy, to form the employees' salaries according to the principle of golden section: salary of employee of a higher level of hierarchy must be $62 \%$ more than a salary of employee of the previous level (table 5).

Table 5. Calculation of the number of hierarchy of staff members and their salaries

\begin{tabular}{|c|c|c|c|c|c|}
\hline \multirow{2}{*}{$\begin{array}{c}\text { Уровни } \\
\text { иерархии / } \\
\text { Levels } \\
\text { of hierarchy } \\
11\end{array}$} & \multirow{2}{*}{$\begin{array}{c}\text { Заработная плата } \\
\text { сотрудника, руб. / Salary } \\
\text { of employee, roubles }\end{array}$} & \multicolumn{2}{|c|}{$\begin{array}{c}\text { Число сотрудников } \\
\text { по уровням / Number } \\
\text { of employees } \\
\text { as per levels }\end{array}$} & \multicolumn{2}{|c|}{$\begin{array}{c}\text { Фонд заработной платы } \\
\text { по уровням, руб. / Wage fund } \\
\text { as per levels, roubles }\end{array}$} \\
\hline & & 1 & & 65000 & \\
\hline 10 & 41232 & 10 & 176 & 412300 & \\
\hline 9 & 25770 & 45 & (17\%) & 1159600 & 3569600 \\
\hline 8 & 16106 & 120 & & 1932700 & \\
\hline 7 & 10066 & 210 & & 2113900 & \\
\hline 6 & 6291 & 252 & & 1585400 & \\
\hline 5 & 3932 & 210 & & 825800 & \\
\hline 4 & 2458 & 120 & & 294900 & \\
\hline 3 & 1536 & 45 & 176 & 69100 & \\
\hline 2 & 960 & 10 & $(17 \%)$ & 9600 & 374200 \\
\hline 1 & 600 & 1 & & 600 & \\
\hline Итого / Total & & 1024 & - & 8468900 & - \\
\hline
\end{tabular}

Установление заработной платы по принципу золотого сечения способствует стабильности и заинтересованности работников и повышению эффективности инвестиций в человеческие ресурсы при условии, что она удваивает
Establishment of wages according to the golden section principle contributes to the stability and commitment of employees and to increase of the efficiency of investments in human resources, provided that it 
объем продаж и должна соответственно увеличить заработную плату каждого работника в 1,62 раза. Статистический анализ показал, что те организации, которые работают по принципу золотого сечения, в среднем повысили производительность труда на 10-20 \%, увеличили оборот в 1,3-1,5 раза, минимизировали затраты на 15-20\%. Применение технологии золотого сечения создает необходимые условия для экономического роста на основе эффективности инвестиций в человеческие ресурсы [4].

\section{ЛИТЕРАТУРА}

1. Лесников И.Н. Инвестиционная составляющая в системе сбалансированных показателей оценки персонала // Управление персоналом. 2009. № 4. С. 47-50.

2. Каплан Р., Нортон Д. Внедрение сбалансированной системы показателей / науч. ред. В. Толкач; пер. с нем. В. Толкача. М.: Альпина Бизнес Букс, 2005. 477 с. (Модели менеджмента ведущих корпораций)

3. Кандалинцев В.Г. Сбалансированное вознаграждение // Методы менеджмента качества. 2006. № 12. С. 28-33.

4. Прангишвили И.В. Повышение эффективности управления сложными организационными и социально-экономическими системами // Проблемы управления. 2005 № 5. C. 28-32.

5. Аржанова И.В., Верстина Н.Г., Ииков А.Д. Показатели оценки деятельности научных подразделений инновационных университетов в контексте модернизации высшего профессионального образования // Письма в Эмиссия. Оффлайн: электронный научный журнал. 2012. № 8. Ст. 1853.

6. Верстина Н.Г., Таскаева Н.Н., Акимова Е.М. Особенности реформирования системы высшего профессионального образования РФ на уровне вузов // Корпоративное управление и инновационное развитие экономики Севера: Вестник Научноисследовательского центра корпоративного права, управления и венчурного инвестирования Сыктывкарского государственного университета. 2012. № 4. С. 2.

7. Верстина Н.Г., Таскаева Н.Н., Акимова E.M. О планировании и реализации проектов реструктуризации вузов // Научное обозрение. 2013. № 3. С. 246-254.

Поступила в редакциюю в апреле 2016 г. doubles the sales volume and should accordingly increase the wages of each employee by a factor of 1.62. Statistical analysis demonstrated that organizations that work using the golden section principle increased the labour productivity on average by 10 $20 \%$, augmented the turnover by a factor of $1.3-1.5$, minimized the costs by $15-20 \%$. Application of the golden section technology creates the conditions necessary for economic growth on the basis of efficiency of investments in human resources. [4].

\section{REFERENCES}

1. Lesnikov I.N. Investitsionnaya sostavlyayushchaya v sisteme sbalansirovannykh pokazateley otsenki personala [The Investment Component in the Personnel Evaluation Balanced Scorecard]. Upravlenie personalom [Human Resource Management]. 2009, no. 4, pp. 47-50. (In Russian)

2. Kaplan, Robert S., and David P. Norton. The Balanced Scorecard : Translating Strategy into Action. Boston: Harvard Business School Press, 1996.

3. Kandalintsev V.G. Sbalansirovannoe voznagrazhdenie [Balanced Remuneration]. Metody menedzhmenta kachestva [Methods of Quality Management]. 2006, no. 12, pp. 28-33. (In Russian)

4. Prangishvili I.V. Povyshenie effektivnosti upravleniya slozhnymi organizatsionnymi i sotsial'no-ekonomicheskimi sistemami [Increasing of Efficiency of Management of Complex Organizational and Socio-Economic Systems]. Problemy upravleniya [Management Problems]. 2005, no. 5, pp. 28-32. (In Russian)

5. Arzhanova I.V., Verstina N.G., Ishkov A.D. Pokazateli otsenki deyatel'nosti nauchnykh podrazdeleniy innovatsionnykh universitetov v kontekste modernizatsii vysshego professional'nogo obrazovaniya [Performance Evaluation Metrics of the Scientific Subdivisions of Innovative Universities in the Context of Modernization of Higher Professional Education]. Pis'ma $v$ Emissiya. Offlayn: elektronnyy nauchnyy zhurnal [The Emissia. Offline Letters : Electronic Scientific Journal]. 2012, no. 8, Article 1853. (In Russian)

6. Verstina N.G., Taskaeva N.N., Akimova E.M. Osobennosti reformirovaniya sistemy vysshego professional'nogo obrazovaniya RF na urovne vuzov [Features of Reforming of the Higher Professional Education System of the Russian Federation at the Level of Higher Educational Institutions]. Korporativnoe upravlenie i innovatsionnoe razvitie ekonomiki Severa: Vestnik Nauchnoissledovatel'skogo tsentra korporativnogo prava, upravleniya i venchurnogo investirovaniya Syktyvkarskogo gosudarstvennogo universiteta [Corporate Management and Innovative Development of Economy of the North: Bulletin of the Research Center of Corporate Law, Management and Venture Investment of the Syktyvkar State University]. 2012, no. 4, Article 2. (In Russian)

7. Verstina N.G., Taskaeva N.N., Akimova E.M. O planirovanii i realizatsii proektov restrukturizatsii vuzov [On Planning and Implementation of Higher Educational Institution Restructuring Projects]. Nauchnoe obozrenie [Scientific Review]. 2013, no. 3, pp. 246-254. (In Russian)

Received in April, 2017. 
О б а в торе: Поташева Галина Анатольевна, кандидат экономических наук, доцент кафедры менеджмента и инноваций, Национальный исследовательский Московский государственный строительный университет (НИУ МГСУ), 129337, г. Москва, Ярославское шоссе, д. 26, potascheva@mail.ru.
A bout the author: Potasheva Galina Anatol'evna, Candidate of Economic Sciences, Associate Professor, Department of Management and Innovations, Moscow State University of Civil Engineering (National Research University) (MGSU), 26 Yaroslavskoe shosse, Moscow, 129337, Russian Federation; potascheva@mail.ru.

Для цитирования:

Поташева Г.А. Инвестиционный аспект в материальном стимулировании человеческих ресурсов // Строительство: наука и образование. 2017. Том 7. Выпуск 1 (22). Ст. 4. Режим доступа: http://nso-journal.ru.

For citation:

Potasheva G.A. Investitsionnyy aspekt v material'nom stimulirovanii chelovecheskikh resursov [Investment Aspect in Material Incentive of Human Resources]. Stroitel'stvo : nauka I obrazovanie [Construction: Science and Education]. 2017, vol. 7, issue 1 (22), paper 4. Available at: http://nso-journal.ru. 